\title{
Penanaman Moral Untuk Meningkatkan Pribadi Berkarakter Remaja
}

\author{
Purwati $^{* 1}$, Nofi Nur Yuhenita ${ }^{2}$, Septiyati Purwandari ${ }^{3}$, Rayinda Faizah ${ }^{4}$ \\ 1,2, Bimbingan dan Konseling, Universitas Muhammadiyah Magelang, Indonesia \\ 3 Pendidikan Guru Sekolah Dasar, Universitas Muhammadiyah Magelang, Indonesia \\ ${ }^{4}$ Psikologi, Universitas Muhammadiyah Magelang, Indonesia \\ Email: bupurwati@gmail.com
}

\begin{abstract}
Abstrack: Tujuan penelitian ini adalah mengembangkan model penanaman moral pada remaja dalam bentuk buku praktis yang dapat dijadikan sebagai panduan bagi para guru, konselor, orangtua, mahasiswa dan praktisi berdasarkan need assement permasalahan dengan melibatkan para stakeholder dalam melakukan penyusunan dan pendampingan. Penelitian ini merupakan penelitian Research and Deveopment (R\&D). Penelitian ini berlangsung 2 tahun. Pada tahun pertama, dilakukan kajian tentang model penanaman moral yang telah dilakukan dan survey perilaku a moral pada remaja yang menjadi permasalahan krusial. Selanjutnya berbagai model intervensi penanaman moral pada remaja dipadukan dengan nilai nilai karaker remaja yang menjadi prioritas untuk diseleseikan. Pada penelitian ini digunakan metode deskriptif kualitatif dalam menghimpun data sedangkan model konseling untuk remaja menggunakan metode literatur review dan metode evaluatif, sehingga tersusun draft model dan buku model penanaman moral pada remaja. Model penanaman moral terdiri dari 5 tahap yaitu pembiasaan, pengamatan, keteladanan, konsekuensi dan pembinaan.
\end{abstract}

Kata Kunci: model penanaman moral, pribadi berkarakter, remaja

\begin{abstract}
The purpose of this study is to develop a model of moral cultivation in adolescents in the form of practical books that can be used as a guide for teachers, counselors, parents, students and practitioners based on need assessment problems by involving stakeholders in the preparation and accompaniment. This research is a Research and Development (R\&D) research. This research lasted 2 years. In the first year, a study was carried out on a moral inculcation model that had been carried out and a survey of moral behavior in adolescents that became a crucial issue. Furthermore, various models of moral cultivation interventions in adolescents are combined with the values of adolescent karaker values which are priorities for completion. In this study, a qualitative descriptive method was used to collect data while the counseling model for adolescents used the literature review and evaluative methods, so that drafted models and book models of moral cultivation were arranged in adolescents. The moral cultivation model consists of 5 stages namely habituation, observation, example, consequences and coaching.
\end{abstract}

Keyword: model of moral cultivation, personal character, adolescence 


\section{PENDAHULUAN}

Di sekolah siswa memerlukan institusi dan sesi formal untuk mendapatkan pengetahuan moral (moral knowing), untuk menghargai nilainilai murni (moral feeling) dan untuk melaksanakan moral (moral action) yang baik. Sebab perilaku dan moralitas tidak terbentuk begitu saja atau membiarkan seorang anak berkembang apa adanya (Hambali, 2015). Oleh karena itu sesi formal haruslah dimuat dalam kurikulum sekolah, di sini kurikulum berperan penting sebagai pemandu yang dapat mengarahkan pendidikan nilai-nilai moral dan karakter kepada siswa. Pembentukan karakter bangsa dapat dilakukan melalui proses pengetahuan (knowing) kepada tindakan kebiasaan (habits). Hal ini bermakna, pengetahuan yang diperoleh diaplikasikan dalam bentuk tindakan melalui latihan dan pendidikan yang berterusan untuk membedakan mana-mana pengaruh yang baik dan keburukan. Untuk tujuan ini, seorang siswa hendaklah dididik secara sadar akan pengetahuan moral (moral knowing), menghargai nilai-nilai yang baik (moral feeling) dan melakukan kebiasaan moral yang baik (moral habits).

Dalam rangka membentuk warga negara yang bertanggung jawab harus ada upaya membuat mereka terinformasi. Pendidikan nilai dapat melakukan tugas ini dengan mengajarkan siswa cara memastikan fakta terlebih dahulu sebelum membuat sebuah timbangan moral. Dari berbagai uraian diatas dapat disimpulkan bahwa institusi pendidikan memiliki peran penting dalam penanaman moral.

Pendidikan moral mencakup pengetahuan, sikap, kepercayaan, keterampilan mengatasi konflik, dan perilaku yang baik, jujur, dan penyayang. Pendidikan moral sendiri terdiri dari beberapa komponen yaitu pengetahuan tentang moralitas, penalaran moral, perasaan kasihan, dan mementingkan kepentingan orang lain, serta tendensi moral. Berbagai kondisi diatas dikaitkan dengan usia remaja memberikan isyarat kepada kita bahwa konsep diri remaja adalah hal yang unik. Pada usia remaja proses sikap assertif menurun, tidak semua anak pada usia tersebut memilik kemampuan untuk mengamati diri sendiri (Juriallik, Laidra, Realo, \& Pullmann, 2004). Beberapa faktor kemerosotan moral pada remaja adalah kurang tertanamnya nilai keimanan, lingkungan masyarakat yang kurang adaptif dan pendidikan moral tidak berjalan sebagaimana mestinya di keluarga, sekolah dan masyarakat (Fahrudin, 2014). Pengetahuan moral (moral knowing) dari keluarga merupakan salah satu landasan dalam mempengaruhi perilaku moral (moral action) remaja, orangtua perlu memiliki pendidikan yang baik agar mampu memberikan pengetahuan moral kepada remaja (Hudi, 2017).

Hal ini membawa arah kepada kita tentang kepribadian usia remaja. Kepribadian menguatkan dan meningkatkan ketahanan psikologis (Grace, 2010). Hal tersebut tentunya membutuhkan situasi lingkungan yang mendukung, terutama lingkungan keluarga. Dalam lingkungan sekolah pola seperti ini tercermin dalam pendidikan karakter.

Pendidikan karakter pada dasarnya dibentuk pada beberapa pilar yang saling berkaitan. Adapun pilar-pilar karakter ini adalah nilai-nilai luhur universal yang terdiri dari:(1) Cinta Tuhan dan alam semesta beserta isinya, (2) Tanggung jawab kedisiplinan dan kemandirian, (3) Kejujuran, (4) Hormat dan santun, (5) Kasih sayang, kepedulian, dan kerjasama, (6) Percaya diri, kreatif, kerja keras, dan pantang menyerah, (7)Keadilan dan kepemimpinan, (8)Baik dan rendah hati, dan (9) Toleransi, cinta damai, dan persatuan.

Selanjutnya, berdasarkan pengamatan yang dilakukan oleh peneliti, faktor-faktor yang mempengaruhi belum optimalnya pendidikan dalam keluarga, antara lain kurangnya pengetahuan dan pemahaman tentang kedudukan peran dan fungsi serta tanggung jawab para orang tua dalam hal pendidikan anak-anak di rumah. Dalam hal ini orangtua yang mampu menerapkan disiplin positif pada anak membantu remaja untuk bisa membangun identitas moral pada dirinya sendiri.

Dari berbagai penelitian tersebut dapat disimpulkan bahwa remaja membutuhkan panduan untuk dapat menemukan konsep diri. Pendampingan yang dilakukan sejak kecil agar pertumbuhan penalaran moral sejalan dengan kecerdasan yang berimplikasi pada kepribadian. Namun demikian, dari berbagai penelitian yang sudah dilakukan ada beberapa hal yang belum dikaji yaitu bagaimana implementasi praktis yang bisa dilakukan oleh orangtua dalam membangun kepribadian yang berkarakter. Tujuan yang ingin dicapai dalam penelitian ini adalah pengembangkan model penanaman moral dalam bentuk buku praktis yang dapat dijadikan sebagai panduan bagi para guru, konselor, orangtua, mahasiswa dan praktisi berdasarkan need assement permasalahan dengan melibatkan 
para stakeholder dalam melakukan penyusunan dan pendampingan.

\section{METODE}

Penelitian ini berfokus pada pengembangan model penanaman moral pada remaja. Penelitian ini dilakukan selama 2 tahun, dan saat ini sedang berjalan pada tahun kedua. Hasil dari penelitian ini dapat dimanfaatkan oleh para pendidik dan guru bimbingan dan konseling untuk mengintervensi berbagai permasalahan moral yang dialami remaja, khususnya di sekolah.

Subyek penelitian pada tahap awal untuk menghasilkan terdeksripsinya permasalahan a moral pada remaja serta nilai nilai karakter sejumlah 45 guru bimbingan konseling se Karisedenan Kedu. Kriteria guru bimbingan dan konseling yang menjadi subyek dalam penelitian ini adalah guru bimbingan dan konseling yang memiliki masa kerja lebih dari lima tahun dan berkerja pada sekolah menengah di wilayah Karisidenan Kedu. Sedangkan subyek penelitian untuk mengukur awal nilai nilai karakter remaja, sejumaah 100 siswa sekolah menengah se karisidenan kedu. Penelitian ini dimulai pada bulan Maret 2018 - Oktober 2018. Diawali dengan focus group discussion atau FGD dengan para guru subyek penelitian untuk mengetahui berbagai permasalahan moral remaja dan juga berbagai hal yang menjadi latar belakangnya. Berdasar hasil FGD ini, langkah selanjutnya adalah menganalisis data menggunakan pendekatan model penilaian kriteria, penentuan prioritas, dan indikator perilaku bermoral dan pribadi berkarakter, serta analisis domain untuk memperoleh gambaran umum tentang data untuk menjawab fokus penelitian. Lokasi Penelitian adalah sampel dari sekolah menengah pertama se Karisidenan Kedu. Proses pengampilan sampel menggunakan metode purposive sampling.

Dikarenakan penelitian ini menggunakan model penelitian dan pengembangan, maka produk akhir dari penelitian ini adalah tersusunnya buku model penanaman moral remaja yang dapat menjadi sumber referensi bagi para guru, konselor/guru BK sekolah menengah, mahasiwa, praktisi dan orangtua. Dalam pelaksanaannya, penelitian pengembangan ini menggunakan metode deskriptif kualitatif dalam menghimpun data sedangkan model- model konseling untuk remaja menggunakan metode literatur review dan metode evaluatif, sehingga tersusun draft model buku model penanaman moral pada remaja. Selanjutnya draft buku model penanaman moral pada remaja ini akan divalidasi oleh pakar dan diujicobakan kepada para guru sekolah menengah.

Analisis data yang digunakan adalah analisis data deskriptif baik kualitataif maupun kuantitatif. Penelitian ini merupakan penelitian Research and Deveopment $(R \& D)$ dengan menggunakan model S. Thiagarajani, Dorothy S. Semmel, dan Melvyn I. Semmel. Prosedur pengembangan memuat 3 tahapan yaitu Define (Pendefinisian), Design (Perancangan), Develop (Pengembangan).

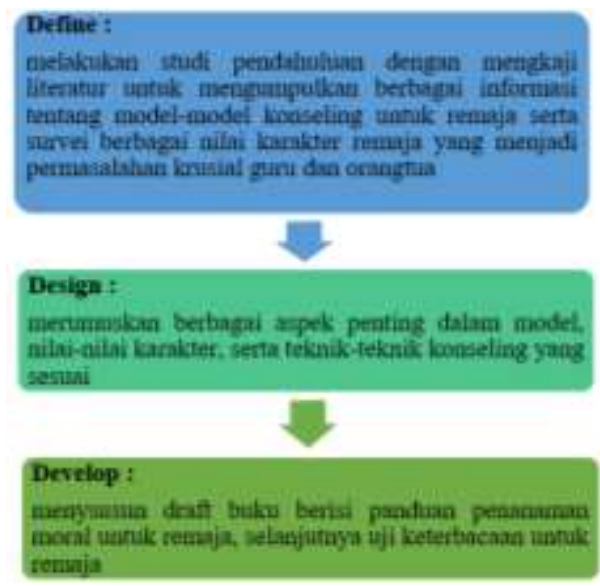

Gambar 1. Tahap Penelitian R and D tipe 3D

\section{HASIL DAN PEMBAHASAN}

Penelitian ini dilakukan melalui kegiatan Focus Group Discusion, Study Literatur dan Uji Coba Instrumen. Focus Group Discusion dimulai dari FGD 1 sampai FGD 5 adalah sebagai berikut:

\section{a. FGD 1 (Permasalahan Moral Remaja)}

Dalam kegiatan FGD 1 bertujuan untuk memetakan permasalahan moral yang terjadi pada remaja. Hasil yang diperoleh adalah sebagai berikut : 1) adanya permasalahan berkaitan dengan perilaku seksual yaitu munculnya free sex ; 2) permasalahan berkaitan dengan pengetahuan tentang karakter yaitu permasalahan tentang kesopansantunan dan tutur kata; 3) permasalahan terkait pemahaman tentang moral sosial yaitu acuh tak acuh terhadap orang lain atau sesama; 4) permasalahan terkait ketrampilan pemecahan masalah yaitu pelampiasan ke hal-hal yang negatif seperti mabuk-mabukan, merokok, 
membolos dan balapan liar; 5) permasalahan terkait kompetensi emosional yaitu mudah tersinggung dan mudah emosi; 6) permasalahan terkait hubungan dengan orang lain yaitu membuat geng, memalak teman dan berkelahi, hal tersebut menunjukkan bahwa perilaku remaja mengarah ke tindakan agresif (Torrente \& Vazsonyi, 2012); 7) permasalahan terkait perasaan keterikatan dengan sekolah yaitu melanggar tata tertib sekolah, membolos, dan vandalism, hal ini sesuai dengan hasil penelitian yang menyebutkan bahwa $96 \%$ remaja melakukan perilaku menyimpang terhadap peraturan yang telah ditetapkan oleh orangtua maupun sekolah (Jayaram \& Caeiro, 2017); 8) permasalahan terkait prestasi akademik yaitu prestasi menurun, tidak naik kelas dan mencontek; 9) permasalahan terkait kompetensi berkomunikasi yaitu nada bicara tinggi dengan teman sebaya dan ceplas ceplos; 10) permasalahan terkait sikap dengan guru yaitu berani dengan guru ketika diberikan informasi seringkali melawan dan tidak memperhatikan pelajaran di kelas.

Perilaku menyimpang anak-anak dan remaja sedang banyak dikaji, tidak hanya untuk mencari cara efektif terhadap dampak kepada masyarakat tetapi juga ke arah pencarian faktor-faktor yang mencegah perilaku tersebut, peran kunci dalam pencegahan perilaku menyimpang di antara remaja dititikberatkan oleh pengaruh keluarga (Vist, 2016). Selain itu, perlunya penetapan aturan yang jelas dilingkungan keluarga maupun sekolah terhadap perilaku remaja (Torrente \& Vazsonyi, 2012). Ikatan sosial dan kontrol diri juga mempunyai peran penting terhadap perilaku menyimpang pada remaja (Cho, 2014). Perilaku menyimpang pada remaja seringkali berwujud berupa pelanggaran terhadap normanorma yang ada di lingkungan sosial maupun di sekolah (Nabiswa, Misigo, \& Makhanu, 2016).

\section{b. FGD 2 (Latar Belakang Permasalahan Perilaku Penyimpangan Moral )}

FGD yang kedua bertujuan untuk memperoleh latar belakang permasalahan dari munculnya perilaku menyimpang pada remaja khususnya siswa SMP. Berikut ini beberapa kategori penyebab Permasalahan Perilaku Penyimpangam Moral berdasarkan hasil FGD yaitu 1) dari lingkungan keluarga yaitu keluarga yang mengalami broken home, taraf pendidikan orangtua yang rendah, adanya kekerasan dalam keluarga, adanya kurang kasih sayang dan perhatian dari orangtua. Kekerasan dalam lingkungan keluarga mampu membentuk karakteristik remaja menjadi lebih agresif, permasalahan sosial dan tingkat kriminalitas tinggi (Frías-armenta \& Corral-verdugo, 2013); 2) lingkungan masyarakat yaitu lingkungan tempat tinggal yang sudah terlabelkan negatif, dan lingkungan yang berpendidikan rendah; 3) teman sebaya atau kelompok yaitu terpengaruh oleh gaya hidup teman yang berlebihan, senada dengan hasil penelitian yang menyebutkan bahwa banyak remaja merasa kurang percaya diri dan secara social mereka menerima saran dengan menjalin kedekatan dengan teman sabaya (Igba, Oka, \& Chidimma, 2016); 4) sekolah yaitu guru yang acuh tak acuh terhadap siswa, letak sekolah yang dekat dengan keramaian, banyaknya tata tertib yang mengekang siswa; 5) media sosial yaitu pemanfaatan IT yang menyimpang, tidak bisa memilah dan memilih medsos secara bijak. Perkembangan teknologi yang cepat harusnya dapat merangsang remaja secara moral dan mampu membuat remaja berkomitmen untuk menunjukkan tindakan yang adaptif (Kaur, 2015).; 6) game online yaitu keasyikan main game online sehingga lupa waktu. Video game menunjukkan tindakan kekerasan berkontribusi pada perilaku agresif terhadap perilaku normal anak muda sehingga mendorong imoralitas (Igba et al., 2016); 7) permasalahan lainnya yaitu ekonomi yang mana keadaan ekonomi yang kurang dapat memicu terjadinya perilaku moral. Status sosio ekonomi rendah meningkatkan angka percobaan bunuh diri yang tinggi, merokok, dan terlibat dalam minuman beralkohol dan dapat menyebabkan tingkat yang tinggi kesulitan perilaku emosional termasuk kecemasan, depresi, gangguan perilaku, agresi dan permusuhan (Igba et al., 2016). Lingkungan keluarga, masyarakat sekitar dan sekolah adalah lingkungan paling penting terhadap perkembangan moral remaja karena di lingkungan tersebut remaja melakukan pengamatan dan modelling terhadap lingkungan sekitar, dan ketika lingkungan tersebut acuh tak acuh maka perilaku maladaptif remaja akan mendapatkan penguatan dan menjadi suatu kebiasaan.

\section{c. FGD 3 (Persepsi Terhadap Nilai Moral Remaja )}

Nilai Moral yang saat ini menjadi peramasalahan utama dalam membentuk insan kompetitif, dengan pemahaman terhadap nilai moral maka dapat terwujud melalui tindakan karakter siswa. Dari berbagai pilar pendidikan karakter yang dilaksanakan disekolah memiliki 
tingkat urgensi yang harus diselesaikan. Beberapa urgensi dikelompokkan menjadi beberapa komponen yaitu permasalahan nilai karakter yaitu (1) : Krusial namun belum begitu berdampak langsung untuk iklim sekolah (2 )Krusial dan mengganggu iklim sekolah (3) Krusial dan Harus segera diseleikan (4) Sudah Terjadi, dan Belum bisa diseleseikan hingga sekarang.

FGD ketiga dilakukan terhadap guru dengan latar belakang menggali persepsi urgensi terhadap nilai moral remaja didapatkan hasil sebagai berikut 1) nilai karakter yaitu sikap dan perilaku yang patuh dalam melaksanakan ajaran agama yang dianutnya, toleran terhadap perlaksanaan ibadah agama lain, serta hidup rukun dengan memeluk agama lain, bentuk penyimpangan yaitu tidak mau sholat dzuhur berjamaah, mengucilkan siswa/teman yang berbeda keyakinan, mengolok-olok agama lain; 2) jujur yaitu perilaku yang didasari pada upaya menjadikan dirinya sebagai orang yang selalu dapat dipercaya dalam perkataan, tindakan dan pekerjaan yaitu sering menyontek ketika ada ujian atau ulangan harian, berbohong kepada guru, memberikan alasan ketika guru bertanya penyebab terlambat; 3) toleransi yaitu sikap dan tindakan yang menghargai perbedaan agama, etnis, pendapat, sikap dan tindakan orang lain yang berbeda dari dirinya yaitu makan di depan orang yang sedang puasa, memotong pembicaraan orang lain, tidak mau memaafkan orang lain; 4) disiplin yaitu tindakan yang menunjukkan perilaku tertib dan patuh pada berbagai ketemuan dan peraturan, bentuk perilakunya adalah datang ke sekolah terlambat, tidak mengerjakan PR, dan saat waktu pelajaran dimulai para siswa memilih untuk duduk di kantin; 5) kerja keras yaitu perilaku yang menunjukkan upaya yang sungguh-sungguh dalam mengatasi berbagai hambatan belajar, tugas dan menyelesaikan tugas dengan sebaikbaiknya. Salah satu bentuknya yaitu remaja tidak bersedia untuk mengerjakan di depan kelas, menyepelekan tugas yang diberikan guru dan menolak untuk belajar; 6) kreatif yaitu berpikir dan melakukan sesuatu untuk menghasilkan cara atau hasil baru dari sesuatu yang telah dimiliki. Bentuk perilaku yang muncul adalah menduplikat karya milik temannya, tidak mempunyai insiatif untuk melakukan pekerjaan namun menunggu perintah dari orang lain; 7) mandiri yaitu sikap dan perilaku yang tidak mudah tergantung pada orang lain dalam menyelesaikan tugas-tugas.
Bentuk perilakunya adalah ketika ada tugas mandiri, remaja tersebut tidak mampu menyelesaikan tugas; 8) demokratis yaitu cara berpikir, bersikap dan bertindak yang menilai sama hak dan kewajiban dirinya dan orang lain; 9) rasa ingin yang sikap dan tindakan yang dipelajari, diamati dan didengar. Bentuk perilakunya yaitu perpustakaan sepi dan jarang pengunjung; 10) semangat kebangsaan yaitu cara berpikir, bertindak dan berwawasan yang menempatkan kepentingan bangsa dan Negara di atas kepentingan bangsa dan Negara di atas kepentingan diri dan kelompoknya; 11) cinta tanah air adalah bentuk cara berfikir, bersikap, dan berbuaut yang menunjukkan kesetiaan, kepeduliaan, dan penghargaan yang tinggi terhadap Bahasa, lingkungan fisik, sosial, budaya, ekonomi, dan politik bangsa; 12) menghargai prestasi adalah sikap dan tindakan yang mendorong dirinya untuk menghasilkan sesuatu yang berguna bagi masyarakat, mengakui dan menghormati keberhasilan orang lain. Bentuk perilakunya adalah iri terhadap prestasi yang diperoleh teman, dan saling menjatuhkan antar siswa; 13) bersahabat/ komunikatif yaitu tindakan yang memperlihatkan rasa senang berbicara, mudah bergaul, dan bekerja sama dengan orang lain; 14) cinta damai yaitu sikap perkataan dan tindakan yang menyebabkan orang lain merasa senang dan aman atas kehadiran dirinya. Bentuk perilakunya adalah membuli teman, memalak teman, membuat keributan saat pembelajaran berlangsung; 15) gemar membaca yaitu kebiasaan menyediakan waktu untuk membaca berbagai bacaan yang memberikan kebajikan bagi dirinya. Bentuk perilakunya adalah malas membaca buku yang berhubungan dengan pelajaran; 16) peduli lingkungan yaitu sikap dan tindakan yang selalu berupata mencegah kerusakan pada alam di sekitarnya dan mengembangkan upaya-upaya untuk memperbaiki kerusakan alam yang terjadi. Bentuk perilakunya yaitu membuang sampah sembarangan, mencorat-coret tembok; 17) peduli sosial adalah sikap dan tindakan yang selalu ingin memberi bantuan kepada orang lain dan masyarakat. Bentuk perilaku yang muncul adalah tidak bersedia menjenguk teman yang sedang sakit, jika ada teman yang kesusahan sering bersikap acuh tak acuh; 18) tanggung jawab adalah sikap dan perilaku seseorang untuk melaksanakan tugas dan kewajibannya, yang seharusnya dia lakukan terhadap diri sendiri, 
masyarakat dan lingkungan (alam, sosial dan budaya).

\section{d. FGD 4 (Permasalahan karakter remaja yang urgen untuk diselesaikan)}

Permasalahan karakter remaja yang urgen untuk diselesaikan adalah nilai karakter jujur, tanggung jawab dan peduli karena karakter tersebut masuk dalam bagian dari kompetensi moral siswa. Jujur yaitu bicara apa adanya, sehingga karakter jujur harus ditanamkan kepada siswa mulai usia dini, karena akan menyangkut karakter anak di masa depan. Tanggung jawab sendiri yaitu melaksanakan tugas dan kewajiban yang seharusnya dia kerjakan sampai selesai, dan peduli sosial adalah tidakan yang selalu ingin memberikan bantuan kepada orang lain, jika peduli sosialnya tinggi maka orang tersebut dengan mudah bersosialisasi dengan orang lain.

Kondisi penyimpangan yang terkait nilai karakter tersebut disekolah adalah nilai kejujuran misanya tidak berbelit belit ketika ditanya, berbicara apa adanya, dan tidak mencotek saat ujian. Nilai karakter peduli adalah menolong teman dari bahaya, membagi bekal makanan, mengantar teman pulang dan meringankan beban guru. Sedangkan, nilai karakter tanggung jawab meliputi melaksanakan piket harian,dan tugas dikerjakan.

Penyimpangan perilaku terkait karakter siswa tersebut dapat diatasi dengan pengembangan model dengan mengimplementasikan belajar kelompok sambil bermain ( Village learning friends), Behavioral atau lebih ke perubahan tingkah laku siswa dan konseling teman sebaya. Kegiatan pembinaan pendidikan karakter diperlukan dapat membentuk remaja yang memiliki itikad baik, sikap yang adaptif, motivasi bagus dan ketrampilan sesuai dengan norma dan budaya Indonesia (Aisyah, 2014). Selain itu, para pendidik/ guru memerlukan buku panduan model penanaman moral. Semakin maju dunia teknologi maka semakin banyak persoalan yang muncul, untuk itu di perlukan adanya banyak literasi, buku-buku panduan yang up to date yang sesuai dengan perkembangan remaja saat ini guna meningkatkan karakter remaja, sehingga bapak ibu guru BK mendapat tambahan ilmu bagaimana cara mengatasi permasalahan anak atau siswa yang semakin komplek. Buku panduan tersebut harus diimplementasikan dengan pelatihan untuk menambah wawasan dan pengalaman terutama tukar ilmu dan tatap muka langsung dengan bapak ibu sesama peserta. Selain itu, lebih memantapkan guru BK dalam mengimplementasikannya tidak cukup dengan teori atau lewat buku saja tetapi perlu adanya praktek-praktek di dunia nyata. Permasalahan pendidikan karakter di kalangan remaja ini akan berhasil ditangani apabila pihak sekolah, masyarakat lingkungan sosial dan keluarga memiliki kesadaran dan bersedia bekerja sama untuk menyelesaikannya (Fatoni, 2017; Sukardi, 2016).

\section{e. FGD 5 (Konsepsi Model Penanaman Moral)}

Bimbingan dan layanan konseling yang dilakukan oleh pemangku pendidikan dapat membantu perkembangan anak dalam membentuk konsep diri positif (Bolu-steve \& Oredugba, 2017; Olando, Otenyo, \& Odera, 2014). Pada FGD ke 5 bertujuan untuk membuat konsep terkait model penanaman moral dengan hasil sebagai berikut :1) teknik assertive training yaitu teknik yang digunakan untuk melatih, mendorong dan membiasakan klien untuk secara terus-menerus menyesuaikan dirinya dengan pola perilaku tertentu yang diinginkannya. Contohnya, seorang murid yang pemalu dilatih pembiasaan diri agar perasaan malunya hilang melalui latihan berdiskusi, memimpin kelompok kecil. Latihan tersebut dilakukan dan ditingkatkan secara bertahap; 2) teknik sosio drama yaitu teknik yang digunakan untuk mengekspresikan berbagai jenis perasaan yang menekan klien melalui suatu suasana yang didramatisasikan sehingga klien bebas mengungkapkan dirinya sendiri secara lisa, tulisan, maupun melalui gerakan dramatis; 3) teknik self modelling yaitu teknik dengan meminta klien berjanji atau mengadakan komitmen dengan konselor untuk menghilangkan perasaan atau perilaku tertentu. Klien diminta untuk tetap setia pada janjinya dan secara terus-menerus menghindarkan dirinya dari perilaku negative; 4) teknik imitasi yaitu klien diminta untuk menirukan secara terus menerus suatu model perilaku tertentu dengan maksud melawan perilakunya sendiri yang negative; 5) teknik reinforcement yaitu teknik yang digunakan untuk mendorong klien kearah perilaku yang lebih rasional dan logis dengan jalan memberikan pujian verbal atau punishment. Teknik ini dimaksudkan untuk menngganti nillai atau keyakinan irasional pada klien dan menggantinya dengan sistem nilai yang positif. 


\section{f. Uji Coba Instrumen}

Instumen yang diujicobakan adalah instrumen yang bertujuan untuk mengukur kepribadian remaja yang berkarakter. Hasil uji coba dinyatakan reliable $r>0,613$ dan dinyatakan valid.

\section{g. Model penanaman moral pada remaja}

Berdasarkan hasil dari FGD dan studi literatur disusunlah sebuah model penanaman moral pada remaja dapat dilakukan dengan beberapa tahap, yaitu mempersiapkan pondasi moral, pembelajaran melalui keteladanan, pembelajaran melalui pembiasaan, pembinaan pengetahuan. Yang mana di dalam tahap ini hendaknya ada lima fase yang harus dilalui yaitu knowing, comprehending, accepting, internalizing, dan implementing. Model ini bisa dijelaskan dalam gambar berikut :

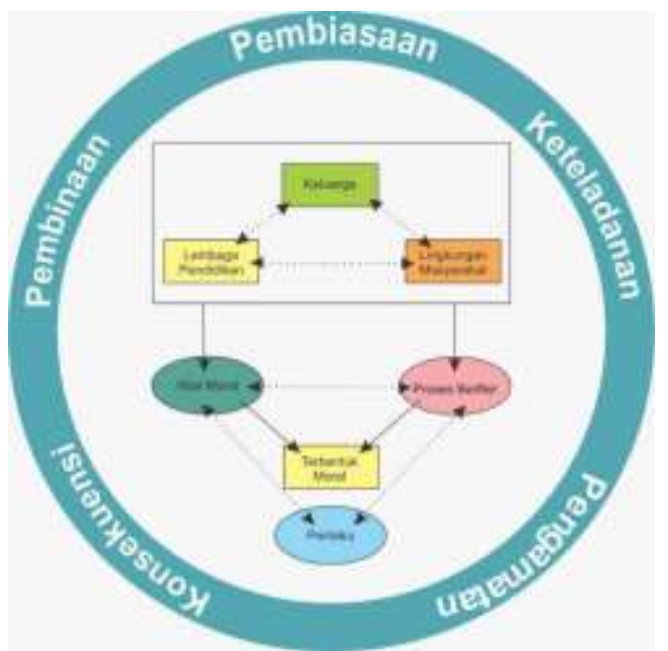

Gambar 2. Model Penanaman Moral

Di dalam proses pembentukan moral diperlukannya interaksi individu dengan sosial dan juga komponen psikologis lainnya. Komponen psikologis dalam penanaman moral meliputi aspek kognitif, afektif, dan perilaku moralitas seperti moral pengetahuan, moral perasaan dan moral tindakan (Lickona, 1999). Pihak-pihak yang mempunyai peran penting dalam pendidikan moral anak adalah orangtua, teman sebaya, guru dan lingkungan sosial (Alavi, 2010).

Ada 5 tahapan dalam model penanaman moral yaitu :

Tahap 1, pembiasaan. Proses pembiasaan merupakan cara bertindak yang diperoleh melalui proses belajar yang dilakukan secara berulang-ulang (Djaali, 2013). Pembiasaan yang konsisten mempunyai dampak yang positif seperti meningkatnya kedisiplinan pada anak (Ihsani, Kurniah, \& Suprapti, 2018). Sesuai dengan pendapat Piaget (1965)perkembangan moral dapat terbentuk dan berkembang karena interaksi sosial. Interaksi yang terjalin secara konsisten antara remaja dengan orang lain merupakan suatu peluang untuk penemuan pribadi melalui pemecahan masalah dan mengeksplorasi norma kelompok dalam masyarakat. Berdasarkan interaksi tersebut juga merupakan sarana bagi remaja untuk melakukan proses pembelajaran dari orang lain dan memahami pendidikan moral berdasarkan pengalaman belajar.

Tahap 2, keteladanan. Berdasarkan konsep social learning menyebutkan bahwa dalam prosesnya, seseorang memulai untuk memunculkan reaksi terhadap lingkungan dan menunjukkan respon, persepsi terhadap self efficacy dan self reactions. Pembejalaran juga berasal dari proses pengamatan dimana adanya proses modelling, retention, representasi simbol, motor reproduction, dan motivasi (Bandura, 1977). Hal tersebut juga dijelaskan oleh Noddings, (2010) bahwa proses penanaman moral bisa dilakukan dengan modelling, yang mana pada proses ini remaja dapat memilih seserorang atau karakter idolanya sebagai model moral baik secara sadar maupun tidak sadar.

Tahap 3, pengamatan. Pembejalaran dan pembentukan moral juga berasal dari proses pengamatan dimana di dalamnya terdapat proses modelling, retention, representasi simbol, motor reproduction, dan motivasi.

Tahap 4, konsekuensi. Pada tahap ini dilakukan practice dan dialogue. Practice adalah proses dimana orangtua dan guru memberikan kesempatan bagi anak-anak atau siswa untuk berlatih meningkatkan kepedulian. Disini anak diajarkan untuk berlatih empati atau simpati. Sedangkan dialogue adalah proses dimana kedua belah pihak berbicara dan saling mendengarkan. Dalam proses dialog orangtuaanak maupun guru-siswa bisa terjadi transfer informasi dan penyelesaian masalah. Tujuan dari dialog adalah mengidentifikasi kebutuhan, apa yang diinginkan dan bekerja sama untuk memenuhi kebutuhan tersebut (Noddings, 2010).

Tahap 5, pembinaan. Di tahap ini terdapat proses confirmation, yang mana merupakan proses dimana pendidik moral mencoba melakukan konfirmasi terhadap anak atau siswa berkaitan dengan motif berperilakunya khususnya perilaku negatif. Contoh adalah menghadapi siswa yang mencotek dalam ujian, maka guru bisa mengkonfirmasi berkaitan 
dengan motif perilaku tersebut. Guru melakukan dialog dengan siswa tersebut dan membantu anak tersebut untuk melihat tindakannya tidak sesuai dengan motif.

Model ini dikemas dalam bentuk konseling dengan mengadopsi beberapa teknik seperti tugas rumah, modelling, role playing dan bebeerapa teknik lainnya. Untuk selanjutnya model ini diujicobakan dalam skala kecil, skala menengah, dan skala besar. Hasil dari model ini sebaiknya diterapkan oleh semua pembimbing baik itu guru mata pelajaran atau guru bimbingan dan konseling.

\section{SIMPULAN DAN SARAN}

Dari data diatas dapat diperoleh hasil penanaman moral pada remaja yang komprehensif terdiri dari 5 tahapan yaitu pembiasaan, keteladanan, pengamatan, konsekuensi dan pembinaan yang dilakukan oleh pihak-pihak di sekitar remaja yaitu keluarga, lembaga pendidikan dan lingkungan masyarakat. Di mana dalam model tersebut nilai moral yang dipelajari dan diamati dari lingkungan akan diolah dalam proses berfikir sehingga terinternalisasi dalam diri remaja dan membentuk moral baru. Internalisasi terhadap moral yang lebih positif harapannya akan membawa dampak pada perubahan perilaku remaja. Hasil dari model ini sebaiknya diterapkan oleh semua pembimbing baik itu guru mata pelajaran atau guru bimbingan dan konseling.

\section{DAFTAR RUJUKAN}

Aisyah, A. R. (2014). The implementation of character education through contextual teaching and learning at personality development unit in the sriwijaya university palembang. International Journal of Education and Research, 2(10), 203-214.

Alavi, H. R. (2010). Al-Ghazali on moral education. Journal of Moral Education, 36(3), 309-319.

Bandura, A. (1977). Social Learning Theory. New Jersey: A Paramount Communications Company.

Bolu-steve, F. N., \& Oredugba, O. O. (2017). Influence of Counselling Services on Perceived Academic Performance of Secondary School Students in Lagos State.
International Journal of Instruction, 10(2), 211-228.

Cho, B. J. (2014). Social Bonds , Self-Control and Deviance of Korean Adolescents. International Journal of Humanities and Social Science, 4(9), 1-8.

Djaali. (2013). Psikologi Pendidikan. Jakarta: Bumi Aksara.

Fahrudin. (2014). Proses pendidikan nilai moral di lingkungan keluarga sebagai upaya mengatasi kenakalan remaja. Jurnal Pendidikan Agama Islam-Ta'lim, 12(1), 41-54.

Fatoni, A. (2017). The Strategy Of Character Education In Globalization Era. International Journal of Scientific \& Technology Research, 6(04), 112-114.

Frías-armenta, M., \& Corral-verdugo, V. (2013). Environmental and Individual Factors in Adolescent Anti-sociality: A Structural Model of Mexican Teenagers. International Journal of Criminal Justice Sciences, 8(December), 198-214.

Grace, F. (2010). The relationship between personality traits and psychological resilience among the caribbean adolescents. International Journal of Psychological Studies, 2(2).

Hambali. (2015). Students' reaction towards nation characters education and the impacts on the practice of nationalist characters. Journal of Applied Sciences, 15(9).

Hudi, I. (2017). Pengaruh pengetahuan moral terhadap perilaku moral pada siswa SMP Negeri Kota Pekanbaru berdasarkan pendidikan orangtua. Jurnal Moral Kemasyarakatan, 2(1), 30-44.

Igba, I. D., Oka, O. I., \& Chidimma, I. L. (2016). Factors affecting the inculcation of moral behaviour in youths within families in ohaozara local goverment area ebonyi state. British Journal of Education, 4(6), 29-43.

Ihsani, N., Kurniah, N., \& Suprapti, A. (2018). Hubungan metode pembiasaan dalam pembelajaran dengan disiplin anak usia dini. Jurnal Ilmu Potensia, 3(1), 50-55.

Jayaram, B., \& Caeiro, D. (2017). Teachers ' Perception about Students Indulging in Deviant Behaviour. The Internatonal Journal of Indian Psychology, 4(2), 84-96.

Juriallik, Laidra, K., Realo, A., \& Pullmann, H. (2004). Personality development from 12 to 18 years of age. European Journal of 
Personality, 18, 445-462.

Kaur, S. (2015). Moral Values In Education. IOSR Journal of Humanities and Social Science, 20(3), 21-26. https://doi.org/10.9790/0837-20332126

Lickona, T. (1999). Character education: seven crusial issues. Action in Teacher Education, 20(4), 77-84.

Nabiswa, J., Misigo, B. L., \& Makhanu, F. N. (2016). Analysis of student deviant behaviour most prevalent in schools of Bungoma County. Journal of Research in HUmanities and Social Science, 4(11), 1923.

Noddings, N. (2010). Moral education and caring. Journal Theory and Research in Education, 8(2), 145-151.

Olando, K. O., Otenyo, B. A., \& Odera, P. (2014). Effectiveness of Guidance and Counseling Services on Adolescent Self- concept in Khwisero District, Kakamega County. International Journal of Human Resource Studies, 4(4), 1-9. https://doi.org/10.5296/ijhrs.v4i4.6498

Piaget, J. (1965). The Moral Judgement of The Child. New York: US: Free Press.

Sukardi, I. (2016). Character Education Based on Religious Values: an Islamic Perspective. Ta'dib: Journal of Islamic Education, 21(1), 41-58.

Torrente, G., \& Vazsonyi, A. T. (2012). Special Issue: Adolescence and Social Deviance Introduction: Adolescence and Social Deviance. anales de psicologia, 28, 639642.

Vist, N. V. (2016). Psychological and Pedagogical Conditions for the Prevention of Deviant Behavior among Adolescents. International Journal of Enviromental \& Science Education, 11(15), 8536-8551. 